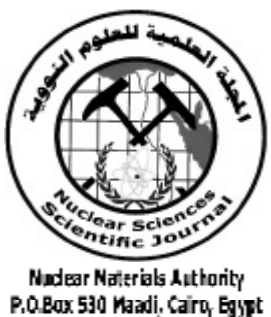

ISSN 2314-5609

Nuclear Sciences Scientific Journal

$6,17-33$

2017

http://www.ssnma.com

\title{
INTEGRATION OF GAMMA-RAY SPECTROMETRIC AND ASTER DATA FOR URANIUM EXPLORATION IN QASH AMER-EL-SELA AREA, SOUTHEASTERN DESERT, EGYPT
}

\author{
IBRAHIM M. GAAFAR; HATEM M. ABOELKHAIR ${ }^{1}$ and MOSTAFA B. BAYOUMI \\ Nuclear Materials Authority, Studies Depart., Maadi, Cairo, Egypt; ' Damietta Univ., Fac. Sci., Geol. \\ Depart., New Damietta, Egypt
}

\begin{abstract}
The present work used the integrated remote-sensing and ground gamma-ray spectrometric data to prospect of radioactive zones at Gabal Qash Amer-El-Sela area, Southeastern Desert of Egypt.

Geological interpretation of ASTER image correlated with field studies revealed that the study area is mainly covered by intermediate metavolocanics, granodiorites, two-mica granites, biotite granites and muscovite granites. These rocks were injected by pegmatitic and quartz veins and cutting by acidic and basic dykes. The applied ASTER data enabled to identify uraniferous alteration zones hosted in the granitic rocks through the use of band ratios $b 4 / b 6$ and $b 5 / b 4$ for clay and ferrous silicate alteration. The band ratio combinations of b12/b13: b11/b12: b14/b13 as R:G:B and b4/b6:b2/b1:b4/b3 as R:G:B were very useful for discriminate the granites from the metavolcanics and mapping different phases of the granite in the study area.

Ground gamma-ray spectrometric survey data were applied to check the surface distribution of radioactivity, which may ascertain its compatibility with surface structures, and delineate the suitable locations for probable valuable mineralization.

The study revealed the existence of uranium mineralization in alteration zones associated with granites, along ENE-WSW trending shear zones as well as other isolated alteration zones. Three uranium-bearing alteration zones hosted in granities were detected. These zones are characterized by ferrugination, silicification, grizenization and kaolinitization. The most promising alteration zones occur at the northeastern part of El-Selashear zone. Another promising uranium anomaly is located to the west of the main shear zone, as well as third anomaly, located at the southeastern part of Gabal Qash Amer. These zones and individual anomalies are characterized by very high radioactive anomalies (up to $3700 \mathrm{ppm}$ eU). Other mineralized sites were detected in the south central part of Gabal El-Selaas well as in the eastern part of the study area. The final result of this study confirms that El-Sela granite can be considered as one of the most promising granite outcrops in Egypt, regarding its U-fertility.
\end{abstract}

\section{INTRODUCTION}

Hussein (1990) stated that Qash Amer granitic rocks are traversed by sub horizontal fissures filled with quartz veins with very limited wolframite mineralization. These granitic groups are represented by monzogranite in composition, calc-alkaline to alkaline in nature and have I-type affinity. Assaf et al. (1998) concluded that the younger granites of Gabal Qash Amer and Gabal El-Sela were generated in extensional environment (within - plate regime) and equivalent to A-type gran- 
ites. El-Gammal and Cherif (1999) mentioned that Gabal Qash Amer area represents an example of tungsten vein deposits associated with alkaline granites. Rashed (2001) stated that Gabal Qash Amer is of monzogranite to syenogranite composition of I- type granite. Masoud (2011) investigated the geology, petrochemistry and radiometry of Gabal Qash Amer granite and considered it as a source for rare metals. Ali (2011) studied the structural control of El-Sela area and defined four structural episodes. (E1) represents a foldingthrusting episode, associated with cratonization of the arc/inter-arc rock association and the intrusion of syntectonic (Older) granites. (E2) represents an upright folding episode, associated with compression and shortening to the ENE-WSW direction, which is different from the NNW-SSE shortening direction during E1. At the end of E2, late tectonic granites were intruded. (E3) represents a post-tectonic granitic intrusion episode. Two-mica granite and granite dykes were intruded during this third episode. (E4) represents a fracturing, faulting, and post-granite dyke extrusion episode that caused different faults that took place after cratonization until the present.

Geological, geochemical, and $\gamma$-ray spectrometric data were integrated to produce a detailed descriptive study of the El-Sela granites. Two types of uranium deposits were recognized: uranium vein type and surficial uranium type (Abd-Elmeguid et al., 2003; Ibrahim et al., 2005, 2009; Gaafar et al., 2006). The latter is due to the prevailing arid to semi-arid weather conditions, which were favourable for forming a pedogenic surficial uranium deposits in the northern part of the study area (Ibrahim et al., 2009). Gaafar et al.(2014) studied core samples that were collected from three boreholes drilled at El-Sela shear zone. They stated that these samples are enriched in large ion lithophile elements (LILE; $\mathrm{Ba}, \mathrm{Rb}$ and $\mathrm{Sr}$ ), high field strength elements ( $\mathrm{Y}, \mathrm{Zr}$ and $\mathrm{Nb}$ ), and LREE, but depleted in HREE, with negative $\mathrm{Eu}$ anomaly. The ratios $\mathrm{Nb} / \mathrm{Ta}$ (7.7-17.7) and $\mathrm{Zr} / \mathrm{Hf}$ (16.9-26.4) are relative- ly enriched in the lighter isovalents ( $\mathrm{Ta}$ and Hf). The accessory minerals, observed in the two-mica granites, are represented by metallic sulphides (pyrite, arsenopyrite, chalcopyrite, galena and sphalerite), Nb-rutile, Hf-zircon, fluorite, monazite, columbite, betafite, thorite, phosphothorite, uranothorite, brannerite, uraninite, coffinite and pitchblende at G. El-Sela shear zone (Gaafar et. al. 2014).

The role of remote sensing techniques in uranium exploration is varied through the definition of lithological, structural and alteration characteristics of metallogenic environments under evaluation (IAEA, 2013). Multispectral remote sensing data have been extensively used in mineralogical and lithological studies on the geology of the Eastern Desert of Egypt in several ways by various authors e.g., Sultan et al. (1986); O'Connor et al. (1987); El Baz (1990); Yousif and Ali (1998); Aboelkhair, et al. (2010); Ramadan et al. (2013); Zoheir and Emam (2014); Salem et al. (2014) and Hassan and Ramadan (2014).

The spatial resolution varies with wavelength: $15 \mathrm{~m}$ in the visible and near infra red (VNIR), $30 \mathrm{~m}$ in shortwave infrared (SWIR), and $90 \mathrm{~m}$ in thermal infrared (TIR). Each ASTER scene covers an area of about $60 \times 60 \mathrm{~km}$. The use of gamma ray spectrometry as a tool for geological mapping, environmental monitoring and exploring radioelement concentrations has found widespread acceptance over several decades and continues to be developed (IAEA, 2010).

The present study aims to delineate and mapping uraniferous alteration zones in Gabal Qash Amer-El Sela area, South Eastern Desert of Egypt, using integrated ASTER and ground gamma ray spectrometer datasets with field and laboratory investigation. This objective also extended to map the different granitic phases and delineate structural trends that control the distribution of the mineralized zones in the study area to conduct an example study needed as a forward step towards the evaluation of such potential areas. 


\section{GEOLOGIC SETTING}

Gabal El-Sela-Qash Amer area lies in the southern half of Elba topographic sheet (NF-37 I), Southern Eastern Desert of Egypt. It represents a part of late Precambrian-early Paleozoic Pan-African Orogeny, forming the Arabian Nubian Shield (950-450 Ma; Kroner, 1984). The area is located between lat. $22^{\circ} 14^{\prime}$ $12^{\prime \prime} \mathrm{N}$ and $22^{\circ} 18^{\prime} 50^{\prime \prime} \mathrm{N}$ and long. $36^{\circ} 11^{\prime} 38^{\prime \prime}$ $\mathrm{E}$ and $36^{\circ} 16^{\prime} 33^{\prime \prime} \mathrm{E}$ with a distance of about $30 \mathrm{~km}$,from the southwest of Abu-Ramad city (Fig. 1). The studied area is topographically low, moderate to slightly high. It is remarkable by Gabal El-Sela (560 m. a.s.1.) and Qash Amer oval-shaped pluton (724 m a.s.1) as well as scattered isolated hills, separated by vast sand sheets.

The area is characterized by Wadi Yoider and Wadi Eikwan (N-S direction) (N-S direction) as well as their tributaries which branch toward the NE direction. Basement complex of El-Sela area is represented by SulHahmidserpentinite, ophiolitic basalt, calc alkaline metavolcanics and related volcaniclastic sediments. The calc alkaline metavolcanics are intruded by El-Sela granites. These granites comprise low to moderate arc-shaped granitic masses that located in the northeastern part of the study area (Fig. 1). They extended to Qash Amer oval-shaped pluton occupying the southwestern part of the study area. These two granite plutons were intruded at a NNW-SSE by Gabal El-Selabiotite granite, which displays an elongated body $\left(9 \times 3 \mathrm{~km}^{2}\right)$. All these granites are surrounded by vast sand sheets. According to geochemical data interpretation, El-Sela granites were derived from high-K calc alkaline magma of adamellitic to proper granitic characters (Abd-Elmeguid et al., 2003).

The granodiorites covering very small zone in the southeastern part of the study area, and forming highly-weathered isolated hills. They were intruded into the metavolcanic rocks, and in their turn, intruded by biotite granites. They are characterized by exfolia- tion texture and contain xenoliths of various sizes and compositions. Gabal Amer is peraluminous granitic rocks and characterized by medium- to coarse-grained, pale pink in color, slightly weathered and affected by joints and fractures. Generally, these granites are syenogranite to alkali feldspar granite and composed of quartz, potash feldspar, plagioclase, biotite and muscovite (Abd-Elmeguid et al., 2003). They are intruded into biotite granites and injected by pegmatitesas well as manganese-, and wolframite-bearing quartz veins. One occurrence of wolframite bearing-quartz veins is recorded in the southern part of Gabal Qash Amer (Takla et al., 1976). Structurally, the study area is characterized by ENE-WSW steeply-dipping shear zones. They are distributed in the study area. Many faults are related to rejuvenation of Allaqi-SulHamid shear system (Ramadan, 2003).

Generally, the different magmatic activities and associated high-fluid phases altered and weakened the granite, making it easily weathered. The development of isolated masses and cavernous shape granites are directly related to their composition and intensity weathering processes. The peripheral rich muscovite granite was greatly affected by weathering agents and outcropping as thin strip at the northeastern part of the study area, as well as other small portions to its southwest part (Fig. 1). These granitic masses are characterized by oval shape withlow to moderate relief.

From the detailed geological map, the granitic masses can be distinguished into two main granitic magmas (Fig. 1). The first mass is a coarse-grained, two-mica granite,with sharp contacted with the remnant thin peripheral muscovite granite. The two-mica granite is light brown in color and composed mainly of quartz, K-feldspar, plagioclase, biotite and rarely muscovite in an equigranular texture. They represent only about $20 \%$ of the twomica granite which shows circular-shaped granite pluton $\left(25 \mathrm{~km}^{2}\right)$. This circular feature more or less characterizes nearly most of the Eastern Desert of Egypt (younger granite plu- 
tons). The second mass is medium-grained granite representing the main bulk of the pluton. This granite is buff to red in color and enriched by pyrite and magnetite. The area is intersected by many fault sets and crosscutting by different acidic, intermediate, basic (including lamprophyre dykes) with various thicknesses and directions.

The main structural trends that affected the studied granite are represented in the E-W to ENE-WSW and N-S to NNW-SSE fault sets, with contemporaneous different injections of fine-grained granite, jasper and basic dykes. The emplacement of these injections along fault sets were associated with high-potential fluids being indicated by alteration haloes. Episyenitization, hematitization, kaolinitization, illitization are the main alteration processes occurred in the study area.

Field observations and detailed mapping indicate that several tectonic events in the study area form a conspicuous shear zoneand affected it. These events are beginning by the emplacement of two granitic magmas followed by an ENE-WSW structural trend that was activated later many times. These activations were contemporaneous with or followed by the emplacement of the multi-color silica injections, micro granites, basic dykes as well as lamprophyre. On the other hand, the N-S left lateral faults trend cross cutting the ENEWSW trend, with lesser rejuvenations (Fig.1). The quartz veins of different thicknesses are strongly jointed, fragmented and brecciated. They show multiphase of white, black, red and yellow staining along joints and fractures. Along the extension of the ENE-WEW shear zone, quartz veins were trapped and digested themicro-granite as altered and bleached pale green lensoidal bodies. Locally, the pegmatite pockets occured along the contacts between

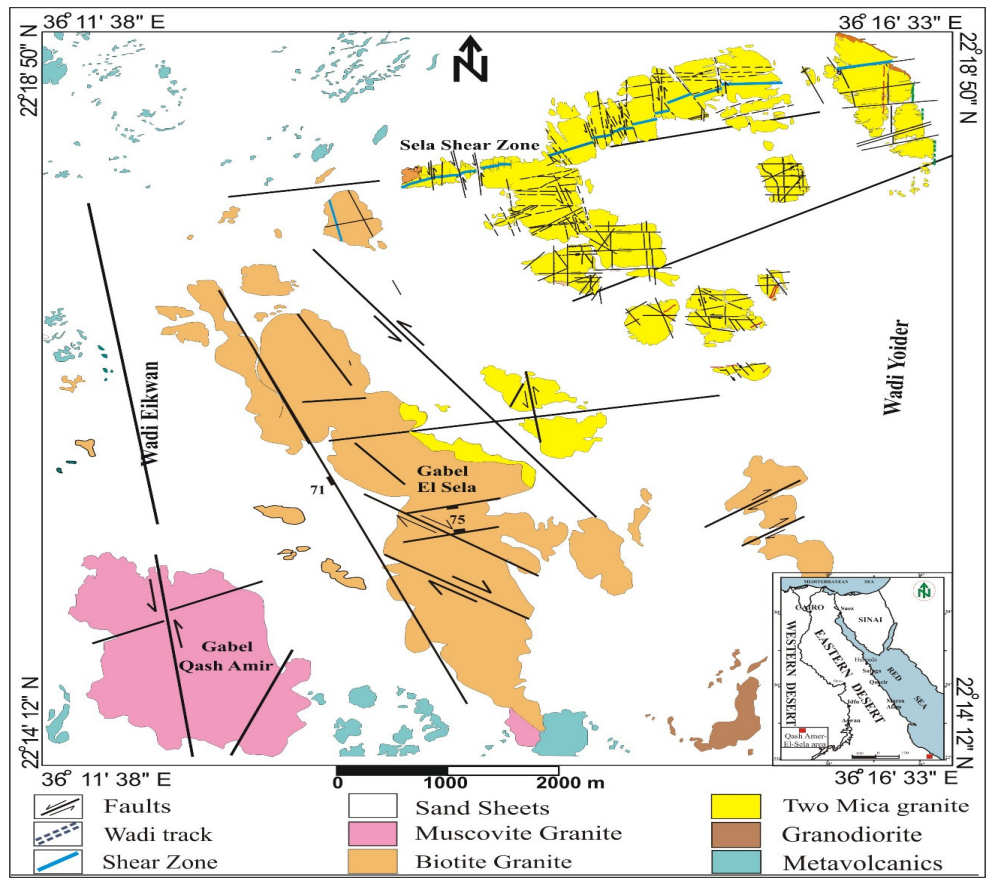

Fig. 1: Geologic map of Qash Amer-El-Sela area, Southeastern Desert, Egypt (Modified after Abdel-Elmeguid, et al. 2003) 
the two granitic magmas. They occur as circular-shaped masses, up to $10 \mathrm{~m}$ in diameter. They are composed of very coarse white crystals of quartz, feldspar and mica.

Gabal El-Sela granite is dissected by some lamprophyre dykes. They are massive, finegrained and range in color from grayish green to dark gray, mostly crosscut by the ENEWSW and N-S structural trends. These dykes are mainly composed of large crystals of alkali-feldspar, embedded in fine basic amygdaloidal groundmass, rich in calcite. The shear zone have higher U-content many times greater than the granite in the study area (reaches 3700 ppm). This shear zone may eventually have play an important role to U-mobilization and possible act as local uranium trap in the study area.

Felsite porphyry dykes invaded the granites in the studied area generally strike in a NW- SE direction. These dykes range in width from veinlet up to $50 \mathrm{~cm}$ (maximum thickness), extended for about $800 \mathrm{~m}$ along the fractures. They are massive, pale pink to yellow in color, fine to aphanitic siliceous groundmass containing plagioclase phenocrysts up to $5 \mathrm{~mm}$ in length. The studied granite are dissected by two sets of felsite dykes, trending in N-S and NE-SW directions. These felsite rocks are fresh or altered and representing latest injections in granite. The fresh type ranges in color from light to deep red, while the altered type is light black to whitish. They are fine-grained, massive and essentially composed of alkali feldspars, amphiboles, iron oxides and very little quartz. Their thicknesses vary from 2.0 to $4.0 \mathrm{~m}$, and extend up to 1.0 $\mathrm{km}$. They are usually fractured and jointed by several sets of joints. Around these dykes, there are intensively altered zones, which indicate their association with high percolated fluids.

The main alterations in the studied granite are episyenitization, illitization, kaolinitization and hematitization. They are recorded as supergene events, occurring as alteration zones along faults and causing mineral redis- tribution. Visible secondary uranium mineralization (uranophane) was recorded as a result of the reactions between the rocks and the successive fluids associated with different magmatic activities (Fig. 2). Hematitizationis also widespread in El-Sela granite, especially along the main structural trends, where jasper enriched with altered pyrite are dominant (Fig. 3). Locally, the episyenite vugs are filled by $\mathrm{K}$-feldspar indicating illitization followed the episyenitization (Fig. 4).

Hematization also is recorded around all felsite injections, where the granite is stained by red color. The ENE and N-S faults were

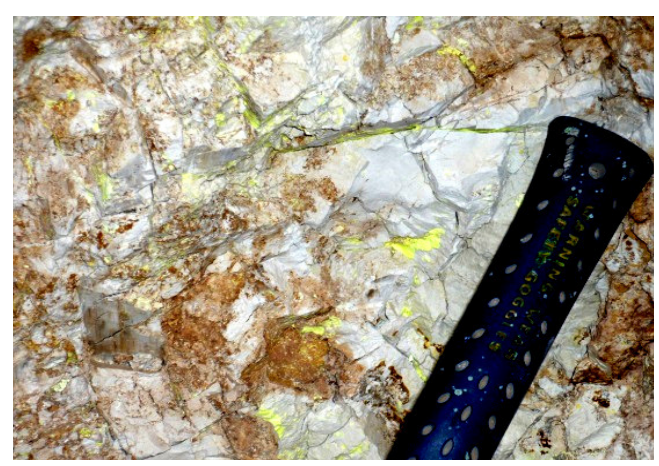

Fig. 2: Intensive secondary uranium mineralization, associated with kaolinitization and hematitization alterations at El-Sela shear zone

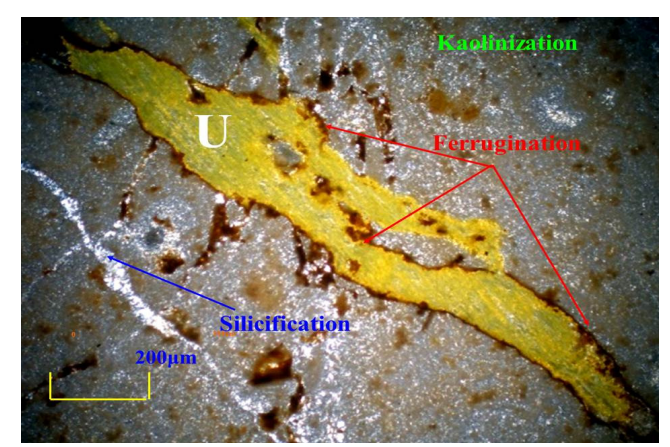

Fig. 3: Photomicrograph showing uranium minerals embedded into kaolinitization and surrounded by ferrogination and silicification at El-Sela shear zone 


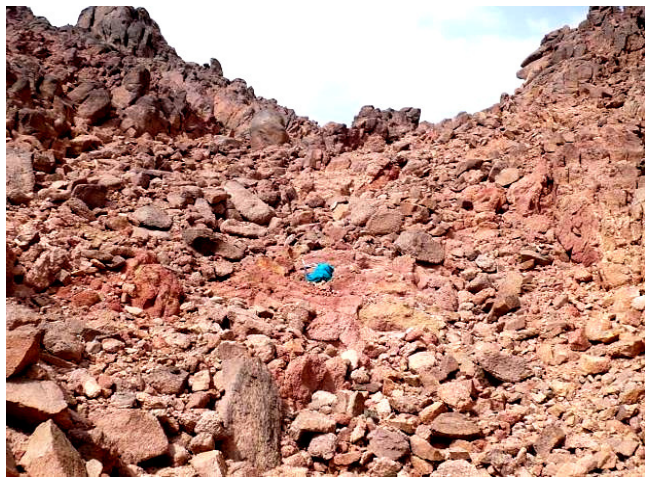

Fig. 4 : Episyenitization spot in coarse-grained twomica granite, El-Sela area

followed by injections of quartz, lamprophyre and felsite dykes along them (Fig. 5).

\section{ASTER DATA PROCESSING}

Stacking of the ASTER (VNIR) and SWIR bands were applied to form 9-band, $15 \mathrm{~m}$ spatial resolution data sets. The images were pre-georeferenced to (UTM) zone 37 North projections with (WGS-84 datum). Since the area of study is smaller than the size of the full ASTER scene $(60 \times 60 \mathrm{~km})$, the sub-setting function was used to trim out the outlier areas and reducing the size of the image.

\section{Band Ratio}

Rationing technique is typically used to enhance the spectral differences between surface materials that are difficult to detect in raw images. This technique may suppress the effects of variable illuminations, resulting from topographic relief (Mather, 1987). The effective band ratios used in this study area for clay alteration mapping was b4/b6 (Fu et al., 2007) and for ferrous silicate alteration mapping was b5/b4 (Hewson et al., 2005).

\section{Band Combination}

By using red, green and blue (RGB) color composite images with band combinations, it is possible to obtain images that differentiate surface materials on the basis of color

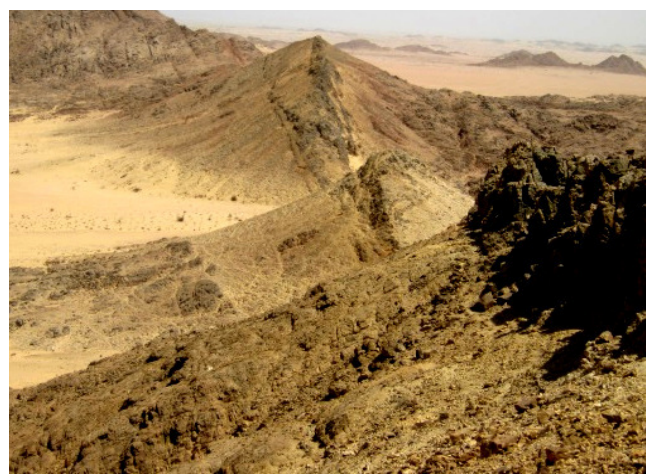

Fig. 5: Multi-silica veins extending to more than $1.8 \mathrm{~km}$ at El-Sela shear zone

variation surface features. Band combinations were created by combining spectral bands to enhance a particular land form or land cover of interest. A significant advantage of multispectral imagery is the ability to detect important spectral differences between surface materials by combining spectral bands.

By selecting particular band combination, various materials may be visually contrasted against their background, using colors. Many band combinations are possible, but convention, logic and information requirements will dictate those that are most useful.

The (TIR) day false color band ratio combination b12/b13: b11/b12: b14/b13 as R:G: $\mathrm{B}$ was used to identify and discriminate between granite and metavolcanic rock units (Aboelkhair et al., 2010). The VNIR-SWIR coloured composite band ratio image $\mathrm{b} 4 / \mathrm{b} 6$ : b2/b1: b4/b3 as R:G:B was also used and proved to be very useful tool for mapping different phases of granites in the study area (Massironi et al., 2008)

\section{GROUND GAMMA-RAY SPECTROMETRIC SURVEY}

Ground $\gamma$-ray spectrometric measurements were conducted to cover a variety of lithologies and various degrees of alterations associated with uranium mineralization in Qash 
Amer-El-Sela area. Major variation trends resulting from data of this survey can be help for understanding the anomalous zones of enriched radioactive elements and evaluating their economic potentialities. Field results show that the studied alteration areas can be successfully mapped using ground gamma-ray spectrometry.

The mineralized fine-grained granite along the shear zone shows a pervasive alteration and a higher degree of fractionation when compared with the non-mineralized granite. The mineralized zones have a high percentage of clay minerals, therefore they become obvious to the naked eye. The Sela shear zone is characterized by abnormally high eU/eTh and $\mathrm{eU} / \mathrm{K}$ ratios. This enrichment in uranium on the expense of both thorium and potassium is associated with the occurrence of discrete uranium minerals. The eU/K ratio is a particularly sensitive pointer, if uranium mineralization is accompanied by sodium metasomatism. Therefore, it is of less practical significance in this case.

\section{Field $\gamma$-Ray Spectrometric Survey}

Ground radioelement concentration measurements were carried out over Qash AmerEl-Sela area in the form of a uniform square grid $(40 \mathrm{~m} \times 20 \mathrm{~m})$ intervals. This grid was densified, and spacing was changed into (5 $\mathrm{m} \times 5 \mathrm{~m}$ ) over the highly mineralized parts. These measurements were conducted using a well calibrated Geophysica Brno (GS-256) spectrometer, having a 0.351 sodium iodide (NaI) thallium ( $\mathrm{Tl}$ )-activated detector and a counting time of 30 seconds.

\section{RESULTS}

\section{Remote Sensing Results}

The ASTER data covered the study area were processed aiming lithological and structural mapping, with particular goal for discriminating uraniferous granites and associated alteration zones. The use of processed ASTER data, in support of field observations enabled us to identify the main alteration zones and hence, construct detailed mapping of radioelements concentration in the study area. The TIR band ratio combinations of ASTER level 2B04 data: b12/b13: b11/b12: b14/b13 as R:G:B composite imagery distinguished obviously the granites from the metavolcanics in the study area as pink color for granites and orange for Metavolcanics (Fig. 6 ). To separate the different phases of granites more clearly, false color image of band ratio combination of ASTER level 2B05 b4/b6: b2/b1: b4/b3 clearly separates GabalQashAmer as pinkish red color and El-Sela granite as greenish blue color (Fig. 7).

The ratio image between bands 4 and 6 suggested by $\mathrm{Fu}$ et al. (2007) differentiated the alterations of clay minerals very clearly as the red colour zones in the pseudocolour image (Fig.8). Three major areas of clay alteration were clearly recognized by using this ratio: Sela shear zone, Southern part of Gabal El-Sela and Gabal Qash Amer (Fig. 8). In addition, some discrete parts lies in the northeast and southeast of the study area. The major part of clay alteration zones in the study area concentrated in the middle of Gabal Qash Amer muscovite granite. The clay alteration associated with Sela shear zone has average thickness of $100 \mathrm{~m}$ and $1500 \mathrm{~m}$ long trending

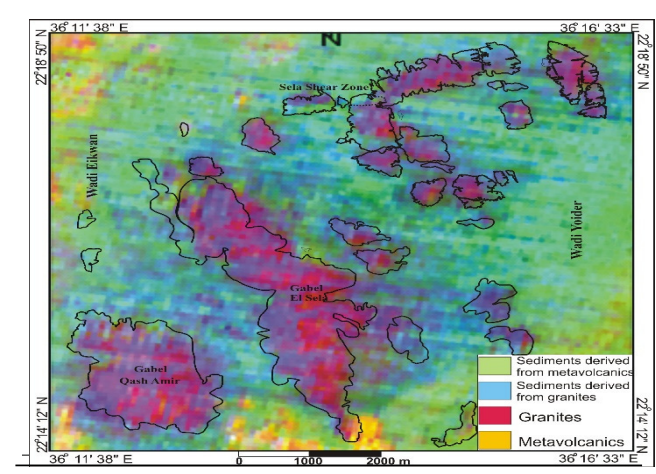

Fig. 6: False color band ratio combination b12/ b13: b11/b12: b14/b13 as R:G:B of ASTER data differentiating the granite bodies and other rock units, Qash Amer - El-Sela area 


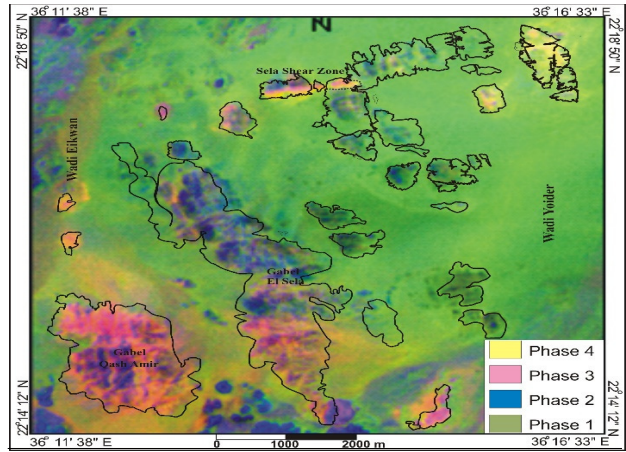

Fig. 7: False color band ratio combination $\mathrm{b} 4 / \mathrm{b} 6$ : b2/b1: b4/b3 as R:G:B of ASTER data mapping the different phases of granites, Qash Amer- El-Sela area

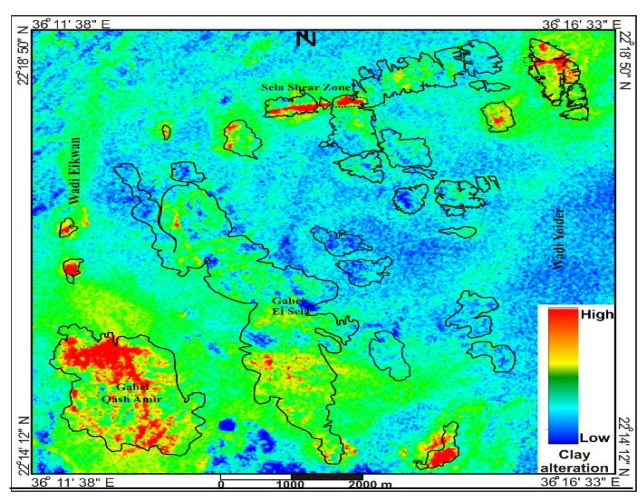

Fig. 8: Pseudocolor image (the range is red to purple denoting high to low values) of band ratio b4/b6 of level 2B05 ASTER data differentiates the clay alteration bodies very clearly as the highly saturated red regions, Qash Amer - El-Sela area

ENE in two-mica granite. In Gabal El-Selabiotite granite, alteration zones are minor and lies in the southern part. In addition, the ratio image of b5/b4 suggested by Hewson et al., (2005) was very useful to differentiate the ferrous silicate alteration as a red color zone in the pseudocolor image as shown on Fig. 9.

The major part of this type of alteration widespread along the north and middle part of Gabal El-Sela biotite granite and in some parts of the middle of Gabal Qash Amer muscovite granite the study area. Moreover, the granodiorite in the southern part of the study area showed high alteration zones of ferrous silicate (Fig. 9). This ASTER band ratio image proved useful for identifying gossans in similar Neoproterozoic rocks of northern Eritrea, where gossans are surrounded by broad zones of clay and iron alteration .

\section{Gamma-ray Spectrometric Results}

In the present study, the ground $\gamma$-ray spectrometric maps (T.C., K, eU, eTh and the binary ratio maps) for Qash Amer-El-Sela area were prepared and subjected to qualitative and quantitative interpretations. These interpretations were carried out to differentiate between rock types, various phases within the same rock types, determine the lithologic contacts, structural lineaments, radiospectro-metric anomalies and associated radioactive mineralizations.

\section{Total-count (T.C., Ur) surface distribution map}

A general view of the surface total-count radioactivity (T.C., Ur) distribution map for QashAmer-El-Sela area (Fig. 10) indicates

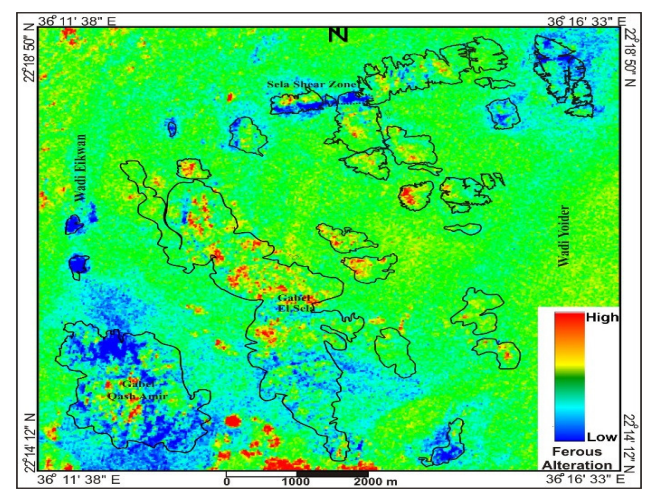

Fig. 9: Pseudocolor image (the range is red to purple denoting high to low values) of band ratio $\mathrm{b} 5 / \mathrm{b} 4$ of level 2B05 ASTER data differentiates the ferrous silicate alteration bodies very clearly as the highly saturated red regions, Qash Amer- El-Sela area 


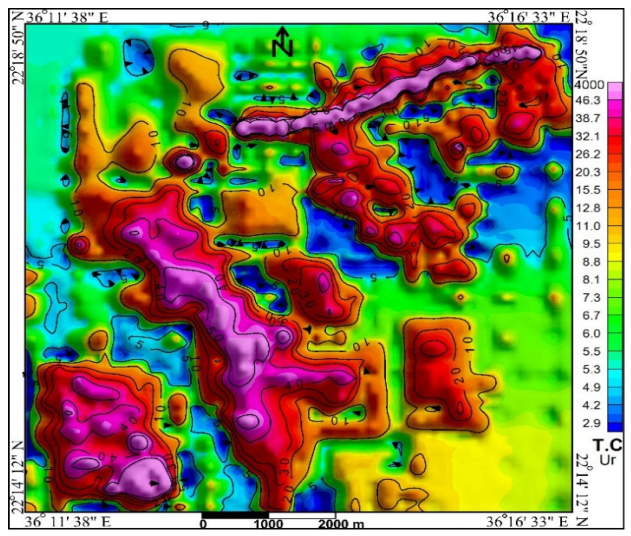

Fig. 10: Total-count (Ur) surface distribution map of Qash Amer - El-Sela area, Southern Eastern Desert, Egypt

that the two-mica granites are discriminated by their relatively low radioactivity without specific trend. These granites do not show any promising anomalies and their radiometric level decreases gradually towards Wadi sediments. A fractured controlled mineralization was located in the shear zone within the twomica granite and in the fractures cutting biotite granites. However, this map clearly exhibits distinctive anomalies over Sela shear zone, reaching to $4000 \mathrm{Ur}$. These high anomalies show raised amplitudes, resulting in obvious exploration targets. This is well demonstrated particularly in the central parts of the area in the form of separated high spots.

\section{Potassium (K, \%) surface distribution map}

The potassium $(\mathrm{K}, \%)$ surface distribution map (Fig. 11) shows that the lowest potassium values $(<1.0 \%)$ are associated mainly with the sheared zone, where its content of K-feldspar has been altered to clay. The shear zone is well discriminated from the country rocks, with its elongated shape and low $\mathrm{K}$ level, trending in an ENE direction. The sediments around the granites have potassium concentrations ranging from 1.0 to $2.4 \%$. The two-mica granite shows higher potassium content, oscillating

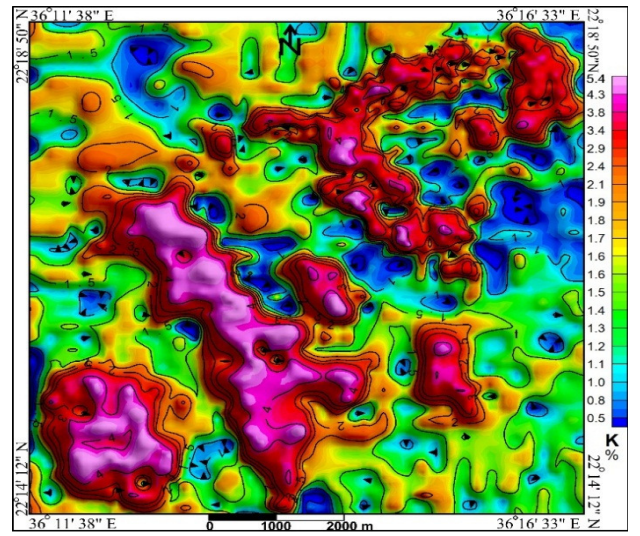

Fig. 11: Potassium (\%) surface distribution map of Qash Amer - El-Sela area, Southern Eastern Desert, Egypt

from 3.5 to $5.0 \%$. It is encountered as zones of irregular shapes and shows increasing Kcontent towards its centers.

The felsite dykes show high level of Kcontent, ranging in intensity from 4 to 5.5 $\%$. They are defined as elongated anomalies, trending along the N-S direction. They show two high K-anomalies attaining $>5.5 \%$, at the southwestern part of the study area. These anomalies have elongated shapes and trend in the NE-direction. This increase in $\mathrm{K}$ content results from the highly-fractured biotitegranite, beside the intrusions of late magmatic finegrained granite and episyenite spots, which are characterized by their high radioactivity level.

\section{Equivalent uranium (eU, ppm) surface distribution map}

The shapes and trends defined by the color image of the eU(ppm) distribution map (Fig. 12) mostly agree with the trends defined the total-count radiometric distribution map. The Sela shear zone is characterized by strong variations in eU concentration values.

The eU concentrations of less than 2.0 ppm are observed over Wadi sediments around the granitic rocks. The uranium range (2-10 


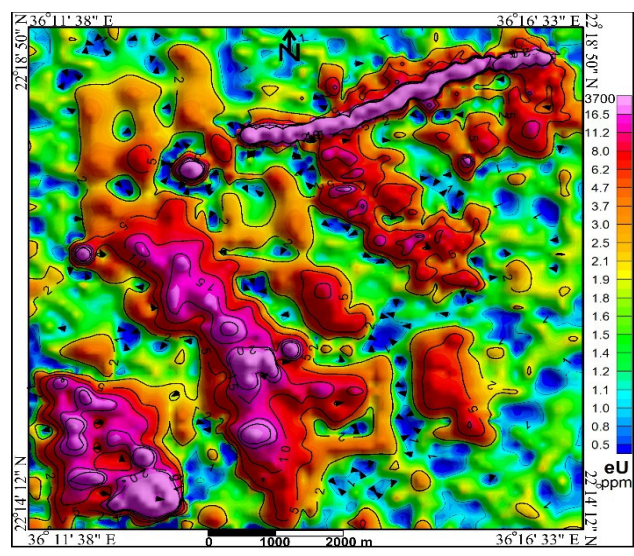

Fig. 12: eU (ppm) surface distribution map of Qash Amer - El-Sela area, Southern Eastern Desert, Egypt

ppmeU) is located over shapes, sometimes is controlled by the main fault trends in the study area. Most of the felsite dykes display eU content ranging from 10 to $40 \mathrm{ppmeU}$. They show sharp gradients with the two-mica granites. Such high range or level is encountered as elongated domains trending in the $\mathrm{NNW}$ direction along the main faults. These eU anomalies reflect secondary uranium remobilization along the fault zones inthe medium-grained two-mica granites. They are encountered as zones with different U-contents, where the main ENE-WNW shear zone attains values up to 1000 ppmeU with relatively low eTh and potassium contents. Such locations proved to represent high U-potentialities of the Sela shear zone.

This high U-potentiality is typically associated with the alteration of the sheared rocks, which are associated with uranium mineralization. This is best developed along the northern parts of the study area. The faults and fractures, which cross the biotite granite, play an essential role in uranium remobilization processes. The process of uranium mobilization towards the shear zone is very important; as such altered rocks were subjected to miner- alization-bearing solutions, where the shear zone acts as a good trap for U-rich fluids or $\mathrm{U}$ - ores in this case.

\section{Equivalent thorium (eTh, ppm) surface distribution map}

Thorium contents usually reflect original rock varieties and the fractionation in this type of granites, especially when thorium content increases. Therefore, eTh content distribution map (Fig. 13) shows well discrimination between the western-located granite (high eThcontent) and the eastern-located two-mica granite (low eTh-content). The eTh content of the shear zone have values ranging from less than 0.2 to $5.0 \mathrm{ppm}$. Such values are encountered around the shear zone and shows sharp gradients with the surrounding granites, with higher Th-contents.

In contrast, the eastern area of the twomica granite is characterized by higher values of $\mathrm{eTh}$ concentrations, ranging from 10 to 30 ppm. Consequently, it appears clearly that the eTh concentrations increase towards the western part of the study area. The eTh-content of the two-mica granite in the western part of the studied area is characterized by a wide range oscillating from 10 to $>80$ ppmeTh, having different shapes of anomalies that are affect-

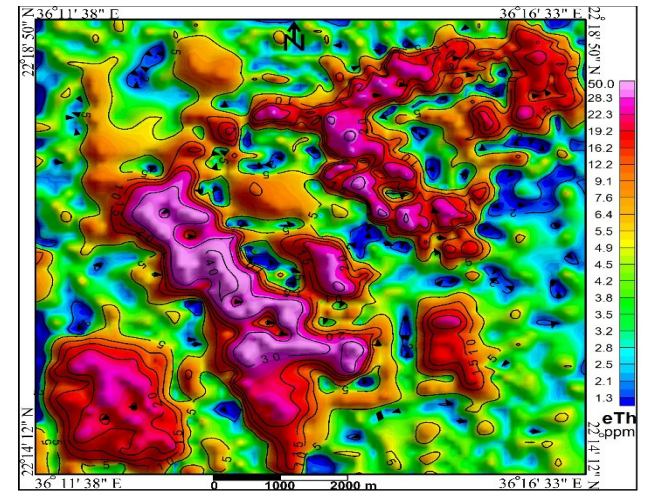

Fig. 13: eTh (ppm) surface distribution map of Qash Amer - El-Sela area, Southern Eastern Desert, Egypt 
ed by the structural setting of the study area. Most of eTh-anomalies occurring in the study area occupied by the two-mica granite. These anomalies are oval-shaped and trend nearly in the NNW direction.

\section{eU/eTh ratio surface distribution map}

The eU/eTh false-colored image map (Fig. 14) confirms the presence of very high eU/eTh ratio zones, reflecting increased uranium content superimposed on the nearly-constant eTh content. The low level of eU/eTh ratio (lower than 0.3 ) coincides with the two-mica granite. The felsite dykes have aneU/eTh ratio ranging between 0.4 and 0.7 and are represented by elongated zones which are trending mainly in the N-S and NNW-SSE directions. The highest anomalies of eU/eTh ratio are associated with the E-W trending shear zone, especially at the intersections of both the E-W and N-S trending main faults. The eU/eTh highly elongated anomalies, which reached 19, trend in

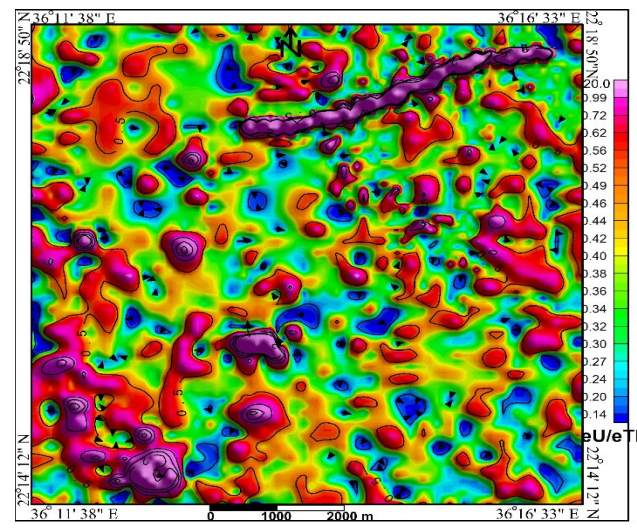

Fig. 14: eU/eTh ratio map of Qash Amer - El-Sela area, Southern E D, Egypt

the E-W to ENE directions and coincide with the sheared zone and fine-grained granite. These anomalies may have been produced by highly enriched solutions in uranium which have permitted the mobilization and the con- centration of this radioelement.

Some uranium was expelled outwards south of the ENE-WSWtrending quartz vein, which intruded into the two-mica granite creating a high eU/eTh ratio anomaly reaching 3.0 .

\section{eU/K ratio surface distribution map}

According to Fig. (15), the Selashear zone is associated with conspicuous, and elongated high anomalies attaining values reaching from 10 to $>110$. This can be attributed essentially to the uranium mineralized shear zone, without any contribution from adjacent granites. The contours of the second high level of eU/K ranging from 2.0 to 12.0 are encountered as zones with different shapes, distributed allover the felsite dykes and mainly associated with the N-S trending faults. The two-mica granites indicate low level of this ratio. The quartz vein, located to the south of the studied area possesses moderate values and forming an E-W trending anomaly.

From the alternative low and high anomalies, especially those associated with the sheared rocks and felsitedykes; the directions of uranium mobilization can be traced towards them, with trends going from the low anoma-

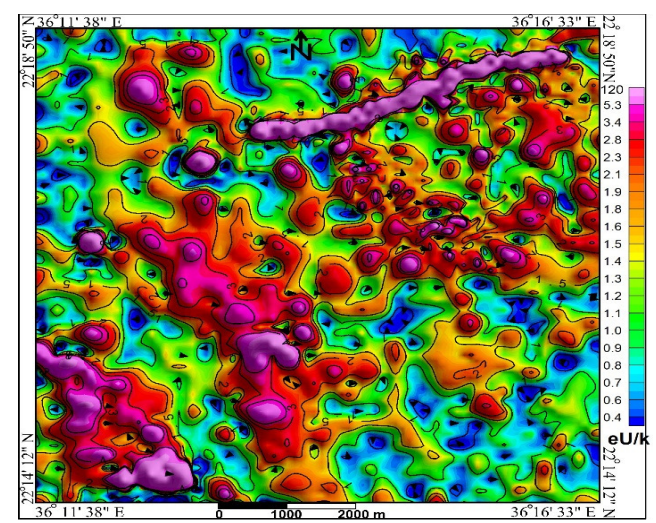

Fig. 15: eU/K ratio map of Qash Amer - El-Sela area, Southern E D, Egypt 
lies to the high positive ones. The shear zone have higher U-content many times greater than the granites leading to an increase in the U-potentiality in their study area.

\section{eTh/K ratio surface distribution map}

Because thorium, as a stable element, reflects original "pre-alteration" compositions, ground $\gamma$-ray spectrometric mapping of bedrock thorium levels permits easy field distinction of different granitic units mistakenly mapped as one type. While spectrometry cannot directly locate base and precious metals, it can detect $\mathrm{K}$ alteration associated with epithermal system and can greatly assist mapping at both regional and properly scales. Therefore, the low $\mathrm{eTh} / \mathrm{K}$ ratio can detect easily alteration zones. The eTh/K contour map, (Fig. 16) shows that the western part of the two-mica granite is clearly discriminated from its eastern part and the shear zone by their high eTh/ $\mathrm{K}$ values reaching to about 8.0. Another high anomaly, reaching to about 12.0 , coincides with the shear zone and defines an elongated belt, trending in the E-W direction. The highest anomalies of $\mathrm{eTh} / \mathrm{K}$ ratio are mostly associated with pegmatitic segregations, which are intruded into the two-mica granite, and having high eTh values. Meanwhile, the eastern part

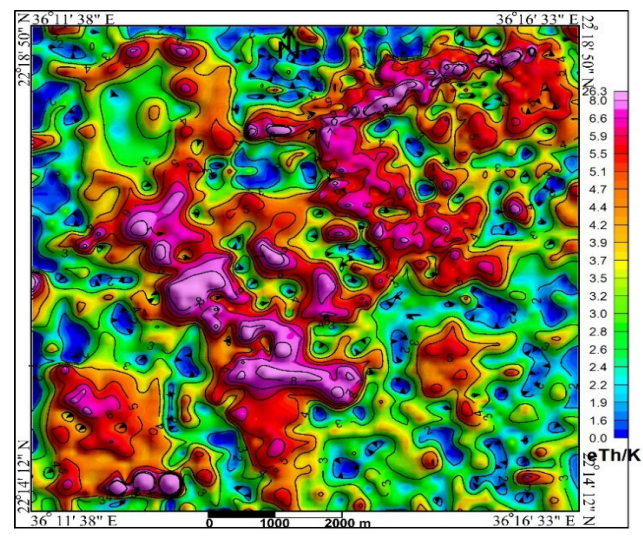

Fig. 16: eTh/K ratio map of Qash Amer - El-Sela area, Southern E D, Egypt of the two-mica granite has low eTh/K ratio, due to its high potassium content relative to its eTh content.

\section{Gamma-ray Spectrometric Ternary Image Map}

Ternary images provide a simultaneous display of the three parameters $\mathrm{K}, \mathrm{U}$ and $\mathrm{Th}$ ratios from ground gamma-ray spectrometry measurements on one image and facilitate, discriminate and delineate the lithological units of the studied area (Fig. 17). The radioelement ternary image combines the data of $\mathrm{K}$ (in blue), eTh (in green), and eU (in red). Obviously, different phases of granites are characterized by an increase of the radioactivity content of the three radioactive elements. Consequently, they appear nearly white in colour. Meanwhile, the radioactivity contents of the three elements decrease sharply around the granites, which are characterized by dark colors as a result of Wadi sediments and country rocks. The highest level (white color) that represents a source of uranium, nearly without potassium or thorium are associated with the ENE shear zone and two circular-shaped anomalies, located at the western part of the studied area, in addition to another one, located in its western part, which are associated

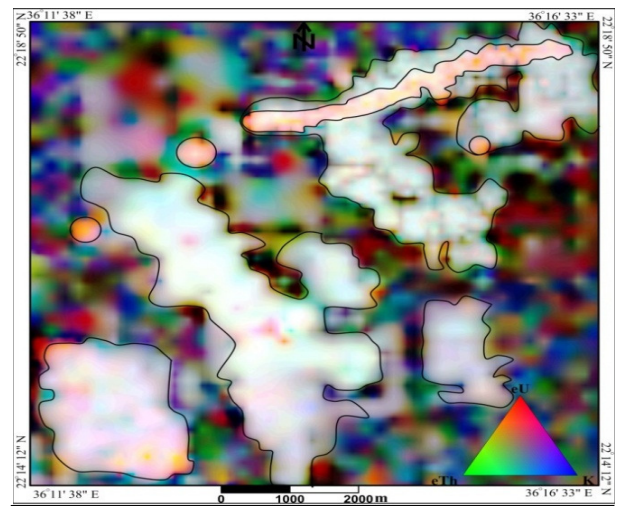

Fig. 17: Composite image map (K, eU and eTh) of Qash Amer - El-Sela area, Southern E D, Egypt 
with uranium mineralization.

\section{DISCUSSION}

Neither satellite nor various geophysical data are able to map all uraniferous alteration zones in Gabal Qash Amer-El Sela area individually. If both data are integrated together, the altered areas can be mapped with more accuracy.

Two main alteration types have been recognized in the study area using ASTER data in support of field observations: clay and ferrous silicate alteration. The results obtained from the ASTER image processing provided information on the spatial distribution of the main alteration zones in the study area (Figs. 8 \& 9). Interpretation of the ASTER SWIR falsecolor ratio images between bands (4) and (6) can differentiate the visually alteration of clay minerals very clearly as red coloured zones (Fig. 8). A visual comparison between the results obtained from the ground gamma ray spectrometry survey (Figs. 10 to 17 ) shows a satisfactory correlation of the spatial distribution of the main alteration minerals at Gabal Qash Amer-El Sela obtained by ASTER data. These zones are associated with high uraniferous granites in the study area mostly in the northwest and southeast areas and associated with G. El-Sela in the southeast areas. In addition, this band ratio reveal that the Sela shear zone completely associated with clay mineral alteration as shown on Fig. (8). These results agree well with the results of gamma-ray spectrometric data especially total count (TC) and equivalent uranium (eU) maps.

On the other hand, the ferrous silicate alteration bodies occurs mainly on the middle and southern sector of the study area and appear as scattered zones on pseudocolour image of band ratio b5/b4 of ASTER data. These results well matched with the of equivalent thorium (eTh) map (Fig. 13) except for the bodies of granodiorite in the southern part of the study area.

The detailed analysis of the $\gamma$-ray spec- trometric measurements indicates that there is an increase in the eU content from 20 to 250 ppmreaching more than 1000 ppmwhen digging in the shear zone. The average abundance of eU reaches about $4 \mathrm{ppm}$ over the two-mica granite. The potassium concentration varies from $0.1 \%$ over basic lamprophyre to $5.5 \%$ over felsite dykes with an average reaching about $3.0 \%$ over the whole study area. The eTh content reaches $50 \mathrm{ppm}$ as a maximum value over the felsite dykes and diminishes to $2.0 \mathrm{ppm}$ over Wadi sediments and basic dyke. The average abundance of eTh in the study area reaches about $23 \mathrm{ppm}$.

The eU/eTh ratio shows a high value reaching 16.4 over the sheared shear zone. It displays lower levels of about 0.1 over the two-mica granite. The $\mathrm{e} \mathrm{Th} / \mathrm{K}$ ratio reaches 30 over the sheared shear zone and muscovite granite and diminishes to a lower value of 1.9 over the two-mica granite. The eTh has different ranges and types of distribution in each group of data. Each group can be classified according to its fractionation stage.

Uranium enrichment is relatively strong in El-Sela shear zone with low eTh-content. This is mainly associated with micro-granite dykes, which were intruded along the dissected fractures in the two-micagranite. The increase of both eU/eTh ratio and eU indicates hydrothermal uranium enrichment. This ratio decreases with increasing eTh for the main part of the coarse-grained granite. Late magmatic U-enrichment is also shown from the increases of eU/eTh ratio with increasing $\mathrm{eU}$ on the main part of the coarse-grained granite. This may indicate a limited redistribution of uranium in the coarse-grained granite, which is associated -to some extent- with the absorbed uranium onto manganese minerals and iron oxides along the N-S trending faults.

Most of the fine-grained granite samples are clustered in between the two values of 2.0 and $4.0 \mathrm{eTh} / \mathrm{eU}$ ratio with simultaneous increase in both Th and U. Therefore, the uranium remained relatively immobile in the original rock. On the other hand, these sam- 
ples are distributed with parallel increases for both $\mathrm{K}$ and $\mathrm{eTh}$. Accordingly, thorium may be concentrated mainly in the primitive phases of magmatic evolution and is present in lesser concentrations in more differentiated phases.

Few samples with potassium values attaining more than $5.0 \%$ were subjected to Kmetasomatism. Some samples with low uranium content (less than $6.0 \mathrm{ppm} \mathrm{eU}$ ) and high thorium content (more than $30 \mathrm{ppm}$ eTh) are characterized by Th-enrichment associated mainly with pegmatite. Few samples, with Uenrichment only, are also visible, which may be associated with altered spots along fractures. Uranium in the two-mica granite has a narrow range of values and the eU/eTh ratio tends to increase, with eU concentration and is independent on thorium concentration.

\section{CONCLUSIONS}

Analysis of ASTER data helped to identify previously-unknown alteration zones in the study area. This proves that remote sensing techniques are useful in exploration for radioactive materials as cheap, time-saving and very accurate methods compared with other tools. This technique needs more corroboration by detailed geological, geophysical and geochemical studies at a regional, semi-detailed and detailed scales to evaluate the radioactive mineralization in this area.

The detailed mapping for the studied area indicates different magmatic activities associated with high-potential fluid phases. The high potential fluid phases altered and weakened the granite making it easily weathered developing the isolated and cavernous arcshaped granitic masses of low to moderate relief. Field relations and observations indicate that the study area was affected by several tectonic events. These events were followed by the emplacement of multi-phase silica injections, micro-granite, pegmatite, as well as basic, lamprophyre and felsite dykes especially within the ENE-WSW and N-S trends. Episyenitization, illitization, kaolinitization and hematitization are recorded as alteration haloes. Visible uranium mineralizations were recorded in El-Sela shear zone. The structural analysis demonstrates a complicated tectonic history where different tectonic activities were recorded along the ENE and NNW directions. These tectonics resulted in a highlyfractured and jointed granite representing a good open system permitting the solution to pass and leach, causing mineral redistribution and concentration. The nearly-perpendicular main shear zones crosscut in ENE-WSW and $\mathrm{N}-\mathrm{S}$ trends, representing wide and long paleochannels for the mineral rich solution. The E$\mathrm{W}$ trending set of faults is older than the N-S trending set where the latter dissects and displaces the former.

To identify and map the different phases of granites in the study areas and alteration zones associated with uraniferous granites, band ratio and band ratio combinations were used. The band ratio (b4/b6) clearly identified the alteration zones in the study area. False color images of band ratio combination of (b12/ b13: b11/b12: b14/b13) as R:G:B clearly discriminate between the granites and metavolcanics as pink and orange regions respectively. A new ASTER colored composite band ratio combination (b4/b6: b2/b1: b4/b3) as R:G:B was applied successfully for mapping the different phases of granites in the study area.

The interpretation of the $\gamma$-ray spectrometric maps indicates that El-Sela granite can be considered very promising, regarding uranium fertility. The N-S structural trend represents a main target, beside the ENE-WSW trend for executing some exploratory drilling and resulting some left lateral strike slip faults. From the structural pattern, it can be noticed that the studied zone shows an increasing and intersecting faults and fractures. This indicates that the mineralization in the study area is structurally-controlled.

\section{REFERENCES}

Abd-Elmeguid, A.A.; Ammar, S.E; Ibrahim, T. M.; Ali, K.G.; Gaafar, I.M.; Khamis, A.A.; Omer, 
S.A; Shahin, H.A.; Masoud, S.M.; Haridy, M. H.; Kamel, A.I.; Mostafa, B.M., and Aly, E. M., 2003. Uranium potential of Eastern Desert granites, Egypt. NMA Report for Model Project (EGY/03/014), sponsored by IAEA, 270p.

Aboelkhair, H., 2010. Processing and interpretation of ASTER TIR data for mapping of rare-metalenriched albitegranitoids in the Central Eastern Desert of Egypt. J. Afri. Earth Sci., 58. No. 1, 141-151.

Ali, K.A., 2011. Structural control of El-Sela granites and associated uranium deposits, Southern Eastern Desert, Egypt. Arab J Geosci, Saudi Society for Geosciences, DOI 10.1007/s12517011-0489-y.

Assaf, H.S.; Ibrahim, M.E.; Ammar, S.E.; Saleh, G.M., and Hashed, M.A., 1998. Geological and mineralogical studies on the radioactive mineral occurrence at Qash Amer area, South Eastern Desert, Egypt. Internal Report, NMA, Cairo, Egypt.

El-Baz, F., 1990. Remote sensing and mapping of earth resources. Terra Rev., 446-454.

El-Gammal, E., and Cherif, O., 1999. Granitoid series and tungsten deposits in the Eastern Desert of Egypt. 12 $2^{\text {th }}$ Symposium on Precambrian and Development, Cairo, Egypt. "Abstract".

Fu, B.; Zheng, G.; Ninomiya, Y.; Wang, C., and Sun, G., 2007. Mapping hydrocarbon-induced mineralogical alteration in the northern Tian Shan using ASTER multispectral data. Terra Nova, 19, No. 4, 225-231.

Gaafar, I.M.; Ghazala, H.,H.; Ibrahim, T.M., and Ammar, S.E., 2006. Gamma-ray spectrometry studies for A Promising Vein Type Uranium Mineralization, South Eastern Desert, Egypt. Proc. $4^{\text {th }}$ Inter. Symposium on Geophysics, Tanta, 445-456.

Gaafar, I.M.; Cuney, M., and Gawad, A., 2014. Mineral chemistry of two-mica granite rare metals: impact of geophysics on the distribution of uranium mineralization at El-Selashear zone, Egypt. Open J. Geology, 4, 137-160.
Hassan, S.M., and Ramadan, T.M., 2014. Mapping of late Neoproterozoic Basement rocks and detection of gold-bearing alteration zones at $\mathrm{Abu}$ Marawat-Semna area, Eastern Desert, Egypt, using remote sensing data. Arab. J. Geosciences, 1-16.

Hewson, R.D.; Cudahy, T.J.; Mizuhiko, S.; Ueda, K., and Mauger, A.J., 2005. Seamless geological map generation using ASTER in the Broken Hill-Curnamona province of Australia. Remote Sensing of Environment, 99, No. 1, 159-172.

Hussein, A.A., 1990. Mineral deposits. In: Geology of Egypt (Said, R., Ed.). Balkema, Rutterdam, $734 \mathrm{p}$.

Ibrahim, T.M.; Cuney, M.; Ali, K.G.; AbdElmeguid, A.A; Gaafar, I.M.; Shahin H.; Omar, S. A.; Masoud, S.M., and Haridy, H.M., 2005. U-fertility criteria applied to El-Sela granite, Southern Eastern Desert, Egypt. Inter. Symposium on Uranium Prod.\& Raw Mater. Nuclear Fuel Cycle, IAEA, Vienna, Austria, 100-103.

Ibrahim, T.M.; Abd-Elghany M.S.; Ali, K.G.,and Gaafar, I.M., 2009. Characterization of new surficial uranium deposit in El-Selaarea, Southern Eastern Desert, Egypt. Accepted for the Geol. Soc. Egypt, Egyptian J. Geology, in press.

International Atomic Energy Agency (IAEA), 2003. Guidelines for radioelement mapping using gamma-ray spectrometry data. IAEATECDOC-1363, Vienna, Austria; 173 p.

International Atomic Energy Agency (IAEA), 2010. Radioelement mapping. IAEA Nuclear Energy Series, No. NF-T-1.3, Vienna, Austria; $108 \mathrm{p}$.

International Atomic Energy Agency (IAEA), 2013. Advances in airborne and ground geophysical methods for uranium exploration. IAEA Nuclear Energy Series, No. NF-T-1.5, Vienna, Austria, 58 p.

Masoud, S.M., 2011. Geochemical characteristics of some peraluminous younger granite masses, Eastern Desert, Egypt. J. Fac. Educ., Ain Shams Univ. 
Massironi, M.; Bertoldi, L.; Calafa, P.; Visonà, D.; Bistacchi, A.; Giardino, C., and Schiavo, A., 2008. Interpretation and processing of ASTER data for geological mapping and granitoids detection in the Saghro massif (eastern Anti-Atlas, Morocco). Geosphere, 4, No. 4, 736-759.

Mather, P.M., 1987. Computer processing of remotely sensed images: An Introduction, John Wiley and Sons; ISBN: 0-471-9064-4

O'Connor, E.A., 1987. Lithotectonic mapping in the Central Eastern Desert, Egypt using enhanced TM imagery. $14^{\text {th }}$ Colloquim on Afri. Geol., Berlin, Germany, 317-320.

Ramadan, T.M., 2003. Use of ERS-2 SAR and Landsat TM images for geological mapping and mineral exploration of Sol Hamid area, Southern Eastern Desert, Egypt. Egypt. J. Remote Sensing \& Space Sci., 5, 13-24.

Ramadan, T.M.; Ibrahim, T.M, and Bayoumi, M. B., 2013. Application of remote sensing in exploration for uranium mineralization in $\mathrm{Ga}-$ balEl-Selaarea, South Eastern Desert, Egypt. Egypt. J. Remote sensing \& Space Sciences, 16, 199-210.

Rashed, M.A., 2001. Geology, petrology and uranium potential of G.El-Sela granitic mass,
Southern Eastern Desert Egypt. M.Sc. Thesis, Mansoura Univ., Egypt.

Salem, S.M.;Soliman, N.M.;Ramadan, T.M., and Greiling, R.O., 2014. Exploration of new gold occurrences in the alteration zones at Barramiya District, Central Eastern Desert of Egypt using ASTER data and geological studies. Arab. J. Geosciences, 7, No. 5, 1717-1731.

Sultan, M.; Arvidson, R.A., and Struchio, N.C., 1986. Mapping of serpentinites in the Eastern Desert of Egypt by using Landsat Thematic Mapper data. Geology, 14, 995-999.

Takla, M.A.; Basta, E.Z.; El-Sharkawi, M.A., and Fawzie, E., 1976. The mineralogy of some wolframite veins from Egypt. Bull. Fac. Sci., Cairo, Univ., Egypt.

Yousif, M.S.M., and Ali, Kh.G., 1998. Use of space imagery and aeroradiometry for delineation of some geologic aspects of Wadi El-Allaqi area, South Eastern Desert, Egypt. J. of Rem. Sens. \& Space Sci., 1, 233-263.

Zoheir, B., and Emam, A., 2014. Field and ASTER imagery data for setting of gold mineralization in Western Allaqi-Heiani belt, Egypt; A case study from the Haimur deposit. J. Afri. Earth Sciences, 99, 150-164.

\footnotetext{
تكامل بيانات الاشعاعية الطيفية والأقمار الصناعية (أستر) لاستكثاف اليورانيوم بمنطقة قش عامر-

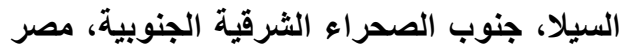$$
\text { إبر اهيم جعفر ، حاتم أبو الخير، مصطفى بيومى جلى }
$$

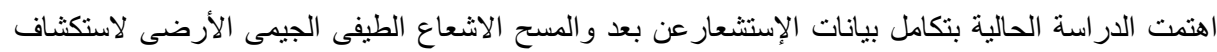

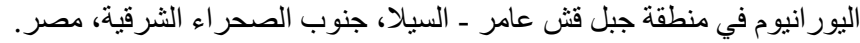

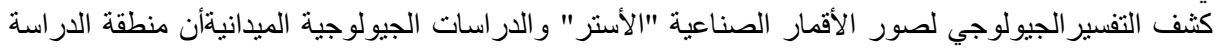

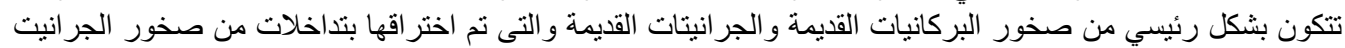

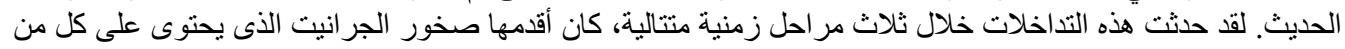

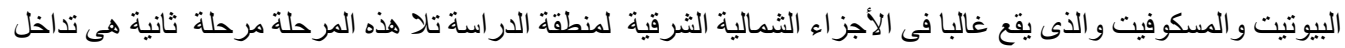

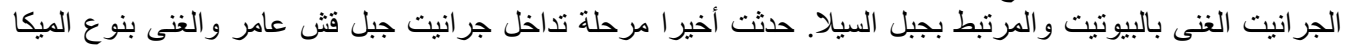

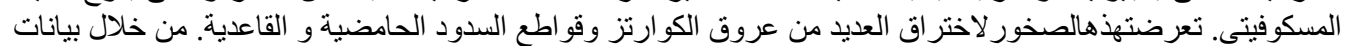

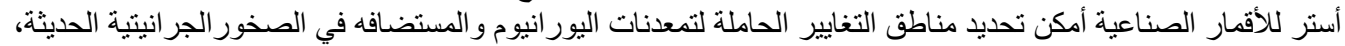

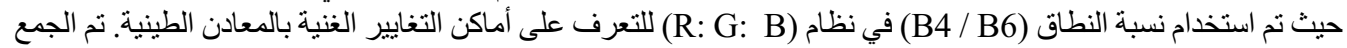

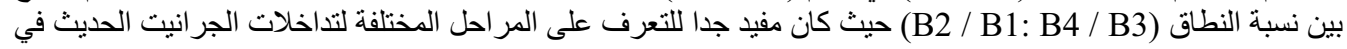


منطقة الدر اسة. تم كذلك استخدام النطاق (B5 / B4) فى التعرف على الأماكن الغنية بأكاسيد الحديد و السيليكا.

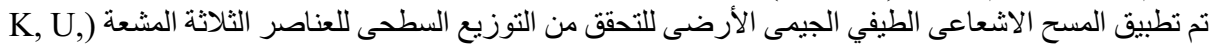

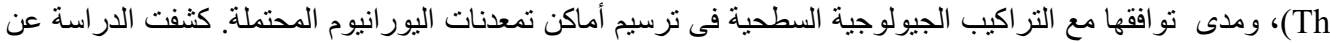
وجود تمعدنات اليور انيوم بتركيز ات عالية ومرتبطة بنطاقات تغاييرتقطع الصخور الجر انيتية، خاصة في نطاق في فص السيلا

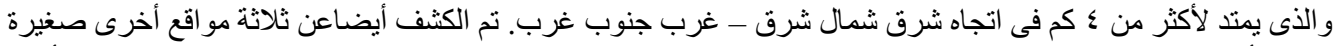

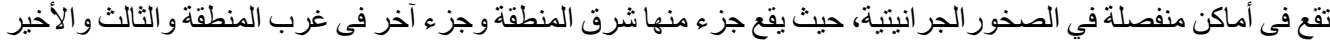

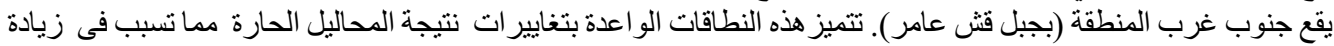

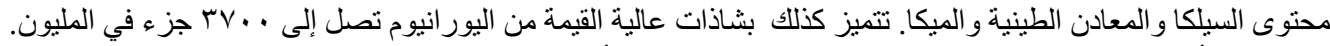

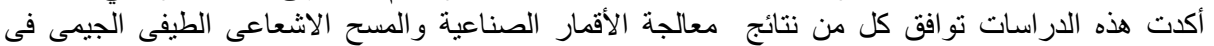

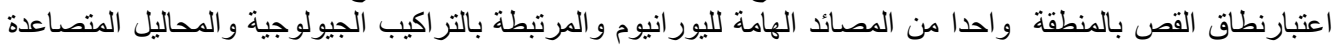

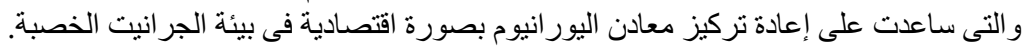

